\title{
Unrequited Love in the Selected Novels of Orhan Pamuk
}

\author{
Ahmed Hassan Ali Murshed \\ Ph.D. Research Scholar \\ Department of English \\ Faculty of Arts, AMU \\ India \\ almurshed2018@gmail.com
}

\begin{abstract}
Certainly, Love is one of the most unmistakable natural sentiments of the individual, so the psychologists have attempted to characterize the word 'love' in various manners, for instance,Freud, in his book, (Civilization and Contents)illuminates the sentiment of love according to mental perspective. As he would like to think, a limit between the 'object' and'ego' is degraded, so he stated that "Against to all proof of his feelings, a person, who is in love utters that 'you' and 'I' are one and begins carrying on as if it was a reality" (Freud, 13). 'Self' of the individual, who falls in love is totally degraded into 'oneself' of the other, so Love assumes an important role in bliss or despondency in human life, in which, the fruitful love makes life upbeat and on the contrary, its disappointment changes life into a hopeless wreck, so unfortunately, Unrequited Love is a one imbalance in which you may love someone with all your heart, but you don't receive these feelings in return. In other words, it is love that isn't reciprocated. For example, you may love someone deeply, but this person simply doesn't love you back.

This paper will discuss the characters' suffering as a result of the one-sided love and explain how they behaved during the events of the love stories, as well as delineate the tragic


ending of their unrequited love, furthermore, it will give some examples from some of Pamuk's novels.

Keywords: Love, One-sided Love, Happiness, Rational, Beauty

Introduction

On June 7, 1952, in Istanbul, the Turkish Nobel Prized novelist and screenwriter, Orhan Pamuk was born to a wealthy family. He studied at Robert College Secondary School, then he went to Istanbul Technical University to study Engineering, but after three years he gave up. However, to become a fulltime writer, he studied and graduated from the Faculty of Journalism at the University of Istanbul in 1976. From 22 to 30 years of his age, he lived with his mother, writing his first novel (Cevdet Bey and His Sons) and endeavoring to find a publisher.

Unfortunately, at the beginning of his young age, Orhan Pamuk fell in love with a girl, he called (the Black Rose). For some time, she frequently was attending to his mother's flat to draw a picture for her, but her parents moved her to Switzerland to study at school there. After some time, she sent him a letter as he stated, "In her letter, that I read in a pudding shop when I was smoking a cigarette, she disclosed to me that she was content with her new school. However, she missed me and Istanbul a lot. I wrote nine letters to her, seven of which I put into envelopes and two of them, I posted. I never got a reply" (Pamuk, Istanbul: Memories and the City, 425). Accordingly, Pamuk was affected by that situation, and it becomes a painful experience for him with love, which in turn reflects his mood in writing emotional and love stories.

Clearly, the female sweethearts in Pamuk's novels seem to be more balanced and reasonable than the male darlings. However, his men are energetic, committed lovers, whereas, 
the women are more practical and rational. They experience passionate feelings for insightful and think all the more essential. Pamuk mentioned to the two kinds of love: erotic and Platonic. His female lovers appear to be platonic in their relationships, while his male sweethearts appear to be more disposed toward the erotic love. The female sweet-hearts never appear to be in a sexual sort of affection. They are mature sweethearts, who can survive their entire lives without enjoying sexual delights. Once in a while, Pamuk's female characters seriously scrutinize their male partner for their lascivious sexual disposition towards the contrary sex.

One-sided Love in Snow

Obviously, Snow, the love story may look like a distraction, a concession to pleasures of a vulgar sort, even (as Pamuk has suggested) a bit of casual camouflage designed to protect the novel from censorship. The love story and especially its female object of desire are depicted in only the most desultory and conventional way. Ka is entranced by Ipek's dazzling beauty; that cliché (repeated later by Orhan) is pretty much all there is to his desire (Robbins, 5). Clearly, Ka is an enthusiastic sweetheart in Snow, who cherishes Ipek, his beloved colleague. He came back to the Kars City with the expectation to come across with Ipek, who was separated from her husband, Muhtar (the colleague of Ka). Ipek reflects a lot of rationality and patience in contrasting with Ka, who truly unveils his affection for Ipek, however she appears to be reserved. At the point, when they truly discuss the issue of what true love implies, she asks Ka for what reason he has become fond of her, Ka comments:

"Since you are so pretty... Since I have just viewed in my dreams how upbeat we will become together... Accordingly, I can disclose to you all things without a 
trace of disgrace. In my fantasies I can imagine constantly usmaking love". (Pamuk, Snow, 129)

Energetically, with a beautiful lady, Ipek, Ka falls in love, but he fails to understand her thoughts. What it will take for him to be happy, Ka says, two things: poetry and Ipek's love. He will get the poetry, at least for as long as he is in Kars, but he will be denied Ipek's love, and denied it by his withdrawal from the cause of his countrymen. Ka has confessed his love for Ipek and said that she is his achance of happiness. Actually, love relationship between Ka and Ipek reaches its last chapter, because of Blue's homicide by the coup soldiers. Strongly, Ka loves Ipek, whereas Ipek claimed to love him in order to overlook her previous love of Blue. Ka gets disappointed because of Ipek's affections for Blue, who in turn, she had been covertly relations with. She is a nice lady, who doesn't surrender easily. Ably,she conceals her previous relation with the Muslim militant, Blue from Ka. She keeps their relations secretly, and controls the entire circumstance. Atlast, she gives up to go with Ka to Frankfurt as his better half, since she questions that Ka has guided the police to her previous darling Blue's whereabouts. She favors to survive with her father and younger sister, Kadife for the rest of her life. The unbeloved protagonist, Ka survives his remnant of the life in absolute pain, and finally,he was killed in Frankfurt by a person of the loyal devotees of Blue.

In a sense, $\mathrm{Ka}$ is finding out here is that Ipek is more honest about her emotions than he is--she knows, as he doesn't, that people do not actually fall in love with each other so quickly. But the idea that Ipek will come to love Ka in the future, in Germany, cannot offset the fact that now, in Kars, even without having seen Blue in months, she still insists that he loves her and not her sister. "'The truth is, Blue doesn't really love Kadife, he loves me!"” (Pamuk, Snow, 392). “'You only want me because you're trying to forget him!' said Ka. Looking into her face, he saw 
with horror that he had spoken the truth" (Robbins, 6).The mere memory of a former love is again enough (set against another backdrop of falling snow) to defeat the protagonist. It is Ipek's certainty of the betrayal that keeps her from leaving on the train with Ka, so this is the first unhappy ending.

\section{Unrequited Love in My Name Is Red}

Undoubtedly, the topics of religion, arts and morality,and love play a significant role in the literature. Certainly, in Pamuk's novels, love is represented in a positive light; for instance, the affection between Black and Shekure is demonstrated to be amazing and advancing, regardless of whether it is likewise, at times, wild. In the novel ofMy Name is Red, love scene of Black and Shekure is the long battle of the lover to acquire his dearest's heart regardless of whatever the sacrifices he has to offer. Black is the darling, who acknowledges all threats and demands in order to win his dearest's heart. He fell in love with Shekure and uncovered it to the family. Subsequently, he had forced to leave home, yet Shekure'slove for Black is very reasonable and not only passionate. Once, Black defines love: "... love is the capacity to make the undetectable notification and the longing consistently to sense the Invisible in one's midst". (Pamuk, My Name Is Red, 139)

Diligently, he endeavors to fulfil the prerequisites set by Shekure, who is a balanced and mature lady, who needs to secure her two orphaned children with the assistance of Black. Clearly, Black is fond of her thoughtlessly and enthusiastically with little consideration of his life security. He fights with the killer and mortally gets injured to carry on with the remnant of his life as a disabled one. Accordingly, he never entertains his married life due to his injured body. 
Simultaneously, love is additionally demonstrated to be risky, especially when it gets fanatical and prompts lost control of oneself. From the beginning of the novel, Esther remarks that Shekure is so profoundly enamored that "obviously, she has gone crazy." Both Black and Hasan become fond of Shekure, in the interim, they badlybehave against each other. Hasan endeavors to assault Shekure, and Black demands that she performs oral sex on him, so these conducts annoy Shekure, who considers that act as a sinful behavior, and drives her to reject that, "if you genuinely loved me, enthusiastically and fanatically... you'd attempt to control yourself like a refined man". Shekure's utilization of the words "energetically and fanatically" spot a light on the issue of sentimental love; despite the fact that it should prompt regard for one's darling and for God, truly it can prompt sexual appetite that are viewed as fiendish and immoral.

\section{One-sided Love in The New Life}

Simply,The New Life represents love and its disappointment in the life of the hero, Osman. In the wake of reading a book, whichknown as The New Life, he meets a young lady named Janan and energetically becomes in her love, but unfortunately, Jananis in love with another person called Mehmet, who vanishes one day. Janan and Osman start a long trip to look for a new life, and after that Osman executes her lost sweetheart, Mehmet with the expectation to wed her, but at the time of returning, Osman discovered Janan's missing. He attempts to locate her out yet it fails. With absolute love disappointment, he loses his life in a street mishap.

Pamuk's enthusiastic darling in the novel,The New Life, Osman characterizes his idea of affection in the following way:

Love is yielding, and it is the reason for affection, as well as it is understood, furthermore it is a sort of music. Love and the delicate heart are indistinguishable, 
and it is the property of distress, as well as it is the delicate soul glancing in the mirror. Love is transitory. Love is never saying you are heartbroken. Love is giving without complaint, and it is sharing a stick of gum. You can never tell about adoration. Love is a vacant word. Love is unpleasant. Love is experiencing the heavenly attendant. Love is an estimation of tears. Love is trusting that the telephone will ring. Love is the entire world, when he/she is holding hands in the cinema. Love is happiness. Love is visually impaired. Love is tuning into your heart,and it is the subject of tunes as well as it is useful for the skin (Pamuk, The New Life, 244-45).

Unfortunately, Osman, the hero does everything is conceivable, to win Janan's heart, but useless, so his brain is in anguish when he realizes his adored Janan fond of with another person and makes him in doubt about his own personality and desires to hold her darling's character, so he stated that "Love... I also might want to take on various identity when I understood tears were gushing from Janan's eyes" (Pamuk, The New Life, 113).

Profoundly, Osman feels that Janan makes her love in his spirit itself, soat the time, when she vanishes from his sight for a long time, he goes through serious sufferings in her non attendance, yet he believes love to be a sweet torture. He looks for her wherever at home and school, however finds no remarks. Once Osman attempted to kiss her on their transport venture, yet she stops him, saying: "No,my dear, no!" she said "You look so like him yet you are not him. He is elsewhere" (Pamuk, The New Life, 78).

Actually, her love for someone else sharply tortures the hero, Osman, who attempts to win her heart, yet she has not surrendered, so her frigidity towards the protagonist (Osman) makes his life horrendous and aimless, on the grounds that she is loyal to Mehmet, whom she attempts to 
look for. The apparition of her memory holds him for the time torturing his spirit, sohe weeps like a little kid in her memory and still longs for her, as well as he desires to even now expresses his love in the following words:

Despite everything, I love you so much...I love you... I prepared to quit any pretense of everything...I'll remain in Germany...I love you so much...I become killers for the sake of you...no don't utter a word...how delightful you are...Don't dwell on it, No one can cherish you as much as me (Pamuk, The New Life, 241).

\section{Unrequited Love in The Silent House}

Clearly,the author depicts the unrequited love of the two high school young men (Hasan and Metin) in The Silent House, in which Hasan attempts to stop for a moment to chat with Nilgun, who doesn't show any enthusiasm for him. Hasan, a youthful patriot kid gets nothing from his one-sided love, because his political belief system becomes predominant, which overwhelms his sentiments. He holds her hand and attempts to powerfully cause her to hear him out and then he blames her for being a socialist, buther calling him 'extremist' drives him crazy and he begins her hitting (Pamuk, The Silent House, 275). Nilgun is mortally injured, however, neglects to counsel a physician. Subsequently, she kicks the bucket of cerebral hemorrhage following day due to the wounds. Unconscious of it, Hasan gets ready to leave the city for eternity and his adoration vanishes with the demise of the honest young lady. Hasan ends the life of his cherished Nilgun with her being a socialist, sotheir relationships appear to be unrequited and end heartbreakingly with complete grievousness of the darlings (Narsingrao, 4).

Unfortunately, the Nilgun's young brother, Metin likewise becomes in love of pretty westernized young lady Ceylan, who entertains her free life with companions. Absolutely, Metin 
falls in her adoration at the first sight, however, he doesn't succeed to gain her heart. On an occasion, he attempts himself force upon her, but it is in vain. The young lady most likely loves another young man and leaves Metin into the dimness. Contrasting with Metin, Ceylan shows a lot of development and pardons him for attempting to attack her, but Metin dreams to win and wed her, however,he can't win his young lady's heart, because she is straight to the point and free with him, at last, he also fizzles to win her likely in light of the fact that she inclines toward another person. Finally, the two little fellows Metin and Hasan individually fall in love of Ceylan and Nilgun, but the two darlings fizzle to win the hearts of their beloveds, so their life end tragically.

One-sided Love in The Black Book

Simply, The Black Book portrays the adoration disappointment topic of the focal character, an advocate, Ghalip, who devotedly cherishes his spouse, Ruya, however she appears to be apathetic and un-infatuated with him. She vanishes one day with leaving a little information. The caring spouse roams all through the city looking for her, changing his personality, andthe recollections of the spouse make his life troublesome and painful.

In TheBlack Bookstory, Ruya's vanishing from Galip's life transforms himself into another person and he starts searching of his lost love. At last, he discovers his spouse dead in a shop which drives the darling into the haziness of melancholy. She takes a peculiar propensity for reading investigator books during the night and nodding off during the day. Galip'slove for Ruya appears to be unrequited love, on the grounds that she never looks content with him, and she never shows up straightforwardly the readers, however, makes her essence through Galip's recollections. He enthusiastically cherishes her privilege from adolescence yet doesn't get the 
equivalent reaction. Clearly Ruya is more pulled in towards her half-brother, Celal, the brilliant journalist, so Ghalip internal sentiments communicate in the following words:

"In his fantasy it was he who was looking for Ruya, not the opposite way aroundjust with the goal that he could feel the torment Ruya fell at this vanishing! Ruya must be in tears, Ruya must be exhausted, after so much time alone, Ruya must be in a dull room, first floor some place, begging him to emerge from his concealing spot!" (Pamuk, The Black Book, 53).

On the contrary, Belkis confesses toGhalip that she has been infatuated with him since their childhoods. She would envision herself inRuya's place that Ghalip used to long for. Her spouse passed away, and she lives as a widow, but Nihat, (Belkis' husband) knew her enthusiasm for Ghalip, however,her spouse was keen on Belkis, as Ghalip had enthusiasm for Ruya and Belkis had enthusiasm for Ghalip. Unfortunately, Belkis attempted to emulate Ruya's just to win Ghalip's affection, andthen she attempted to be free from this obsession, but she fails, and became unable to overlook Ghalip.

\section{Sad Ending of Love in The Museum of Innocence}

Obviously, The Museum of Innocence, is a romantic story happens principally somewhere in the range of 1974 and 1980, which discusses a youngster from an affluent, westernized Istanbul family, it is the longest, and best love story composed by Orhan Pamuk,in which he portrays the adoration and interest of the hero, Kemal for a poor shop young lady,Fusun. Clearly, Kemal appreciates the sexual love with a young lady disregarding his being engaged with another young lady,Sebel. Explicitly, at first, he appears to be pulled in towards the young lady, yet after her vanishing, he becomes more fixated of her. 
Thoughtlessly, he roams in the city of Istanbul to discover his lost love. He succeeds, yet he discovers that she has already got married with another person. The ardent sweetheart with his horrendous obsession visits her home for the next ten years lastly prevails to persuade her separating from the spouse. He discovers comfort in gathering everything he cherished has ever contacted. At the end of the novel, he decided to take her items from everyday life - postcards, photos, matchsticks, saltshakers, keys, dresses, film cuts, and toys, mementoes of his bound relationship and of the Istanbul of the 1970s and 80s, whose roads he meandered with his sweet heart and shows them in a museum (Pamuk, The Museum of Innocence, 324). He gathers the materials of his darling and establishes a museum after her coincidental demise. The heroes of this woeful romantic story had kicked the bucket, and the house they had lived in, had been changed over into a historical museum (Narsingrao, 5).

\section{Conclusion}

Basically, Love is a unique characteristic of the unmistakable sentiments of the individual, so the social scientists have attempted to determine the word 'love' in various manners. Many times, unreasonable, the sentimental and rich image of affection with cheerful closure are depicted by the artists. In any case, it isn't generally upbeat since it has numerous twists, deal with in actuality. Since the modern time of the narration, which has gotten more reasonable, the writers likewise depict the image of sensible love and its disappointment in their works, so love disappointment in practical life additionally turns into a significant subject in romantic novels and stories.

Pamuk's attractive and capable men strongly fall in love of the wonderful ladies, entertain themselves, but unfortunately, the tragic end was the result of their love, for instance, Ka, Black, 
Osman, Metin, Hasan, and Kemal are the one-sided sweethearts, who love their beloveds with no reaction from them. Their adoration is totally unrequited and its grievous end is sure. Love in Pamuk's stories is anything but not a customary sentimental kind, yet has genuine obstacles. Since his novels are sensible, the characters and topics also originate from genuine existences of individuals, so Love has another clouded side which may be additionally overwhelming. 


\section{Works Cited}

Freud, Sigmund. “Civilization and Its Discontents.” W.W. Norton Company Press, vol. 32, no. 6, 1976, p. 109, doi:10.1080/07351690.2012.703896.

Narsingrao, Pawar Meghraj. "Love and Its Failure in the Novels of Orhan Pamuk." The Novels of Orhan Pamuk: A Study in Major Themes, 2016, p. 53.

Pamuk, Orhan. The New Life. Trans. Guneli Gun. New York: Farrar Straus and Giroux, 1997. Print

---. My Name is Red. Trans. Erdag M. Goknar. New York: Alfred A. Knopf, 2001. Print

---. Snow. Trans. Maureen Freely. New York: Alfred A. Knopf, 2004. Print

---. The Black Book. New Trans. Maureen Freely. New York: Alfred A. Knopf, 2006. Print

---. The Museum of Innocence. Trans. Maureen Freely. New York: Alfred A. Knopf, 2009. Print

---. The Silent House. Trans. Robert Finn. New York: Alfred A. Knopf, 2012. Print

---. Istanbul: Memories and The City. Trans. Maureen Freely. New York: Alfred A. Knopf, 2004. Print

Robbins, Bruce. Love Triangle in Pamuk's Snow.1. No. 222, 2010, pp. 1-17. Trans, Maureen Freely. Snow. 2003. 